\title{
2020 Pantanal's widespread fire: short- and long-term implications for biodiversity and conservation
}

\section{Guilherme A. V. Mataveli ${ }^{1}$ (D) - Gabriel Pereira ${ }^{2,3} \cdot$ Gabriel de Oliveira $^{4} \cdot$ Hugo T. Seixas $^{5}$. Francielle da S. Cardozo ${ }^{2}$. Yosio E. Shimabukuro ${ }^{1}$. Fernando S. Kawakubo ${ }^{3}$. Nathaniel A. Brunsell ${ }^{6}$}

Received: 14 October 2020 / Revised: 10 June 2021 / Accepted: 28 June 2021 /

Published online: 2 July 2021

(c) The Author(s), under exclusive licence to Springer Nature B.V. 2021

\begin{abstract}
The Pantanal faced an unprecedented drought event in 2020. The hydrological year ended in July, 2020 had an annual average rainfall 26\% lower than the average from 1982 to 2020. Consequently, catastrophic wildfires burned out of control. Active fires during this year have also increased, and were 123\% higher than the 2002-2020 Pantanal's average. Approximately $95 \%$ of these active fires occurred in natural land covers with $28 \%$ of them occurring in areas classified as wetlands that likely dried out due to the drought. Therefore, the development of a special policy is needed to minimize the impact of this crisis on the biodiversity, conservation, and traditional people of the Pantanal.
\end{abstract}

Keywords Wetlands · Drought $\cdot$ Burning $\cdot$ Biodiversity Threat $\cdot$ Conservation

A recent report on the global state of biodiversity has shown that targets set 10 years ago to protect natural vegetation areas were not achieved due to rapid and substantial changes in agriculture, industry, and other activities that increased the rate of biodiversity loss

Communicated by Lilly O Rodriguez.

Guilherme A. V. Mataveli

mataveli@alumni.usp.br

1 Earth Observation and Geoinformatics Division, National Institute for Space Research, São José dos Campos, São Paulo, Brazil

2 Department of Geosciences, Federal University of São João del-Rei, Minas Gerais, São João del-Rei, Brazil

3 Graduate Program in Physical Geography, University of São Paulo, São Paulo, São Paulo, Brazil

4 Department of Earth Sciences, University of South Alabama, Alabama, Mobile, United States of America

5 Center for Environmental Studies and Research, University of Campinas, São Paulo, Campinas, Brazil

6 Department of Geography and Atmospheric Science, University of Kansas, Kansas, Lawrence, United States of America 
(Stokstad 2020). This situation is also occurring in wetlands, considered world biodiversity hotspots (Keddy et al. 2009) where most of biodiversity loss is related to anthropogenic disturbances.

Located in the center of South America, the Pantanal is the largest tropical wetland in the world. This seasonally flooded wetland consists of a complex mosaic of ecosystems shaped by several interconnected natural and anthropogenic factors; therefore extremely sensitive to disturbances. The Pantanal faced an unprecedented drought event in 2020. Data from the Climate Hazards center InfraRed Precipitation with Station data (CHIRPS) (Funk et al. 2015) demonstrated that the hydrological year ended in July, 2020 was the driest one ever registered by this dataset, $26 \%$ lower than the annual average rainfall from 1982 to 2020 (Fig. 1). This drought event initially began with the occurrence of marine heat waves in the Northeast Pacific Ocean (Thielen et al. 2021). Modelling studies have predicted a significant increase in the occurrence of severe and prolonged drought events in the Pantanal during the near future, triggered by warming sea surface temperatures in the Northern Hemisphere (Thielen et al. 2021; Thielen et al. 2020).

As a consequence of the unusual dry conditions, catastrophic wildfires burned out of control. The main drivers of the Pantanal's fires are the same as those causing the Amazonian burning crisis (Barlow et al. 2020), but this scenario is more devastating due to favorable meteorological conditions. Evidences point out to the fact that local farmers took advantage of the dry conditions to set arson fires in natural vegetation areas aiming to expand pasturelands for cattle ranching (Morel 2020).

These wildfires have impacted almost one-third of the Pantanal area exceeding $40,000 \mathrm{~km}^{2}$ (Libonati et al. 2020), causing several species of this biodiversity hotspot to struggle for survival (Lemos 2020) and mobilizing volunteers to rescue injured animals (Langlois 2020). Consequently, smoke from the Pantanal's fires covered neighbor countries and the largest and most populated city of Brazil, São Paulo (1,200 km distant from the Pantanal) in mid-September (Pinheiro 2020). This caused a particular risk during the COVID-19 epidemic as the respiratory health impacts of smoke pollution are likely to interact with the epidemic and worsen infection (de Oliveira et al. 2020). According to the Brazilian official fire monitoring program (INPE 2020), Moderate Resolution

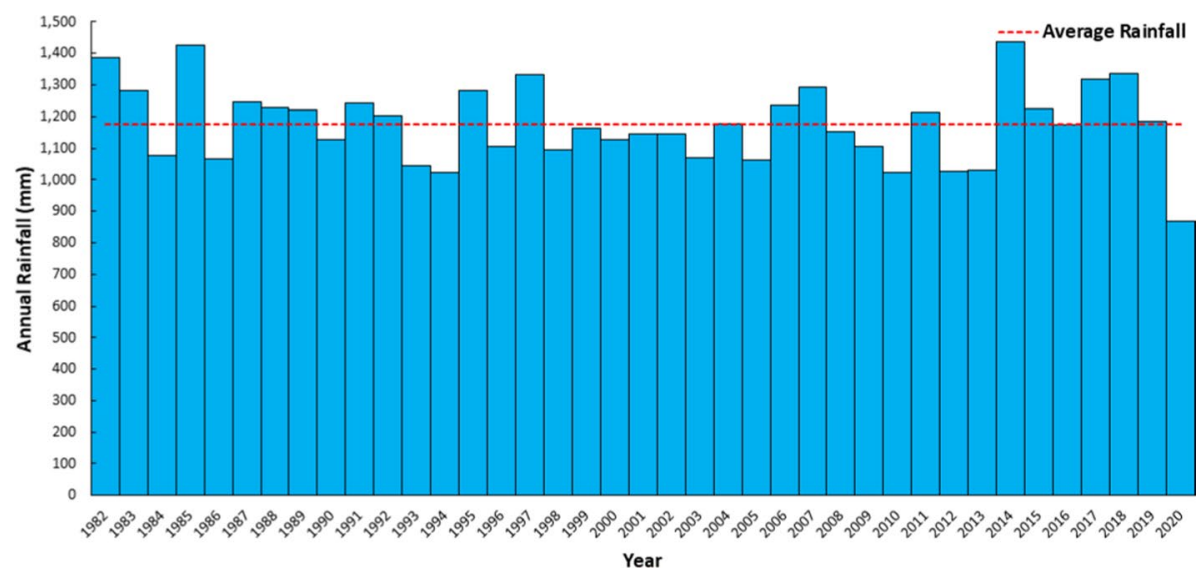

Fig. 1 Annual rainfall estimated by CHIRPS in the Pantanal from 1982 to 2020. We have considered the hydrological year for the region, for example, 2020 corresponds to the period from 08/01/2019 to $07 / 31 / 2020$ 
Imaging Spectroradiometer (MODIS) sensors have recorded the highest number of active fires detected in the Pantanal during the hydrological year ended in July, 2020 (Fig. 2), 123\% higher than the 2002-2020 average. Active fires from August to October 2020 have also set the monthly record in this historical time series.
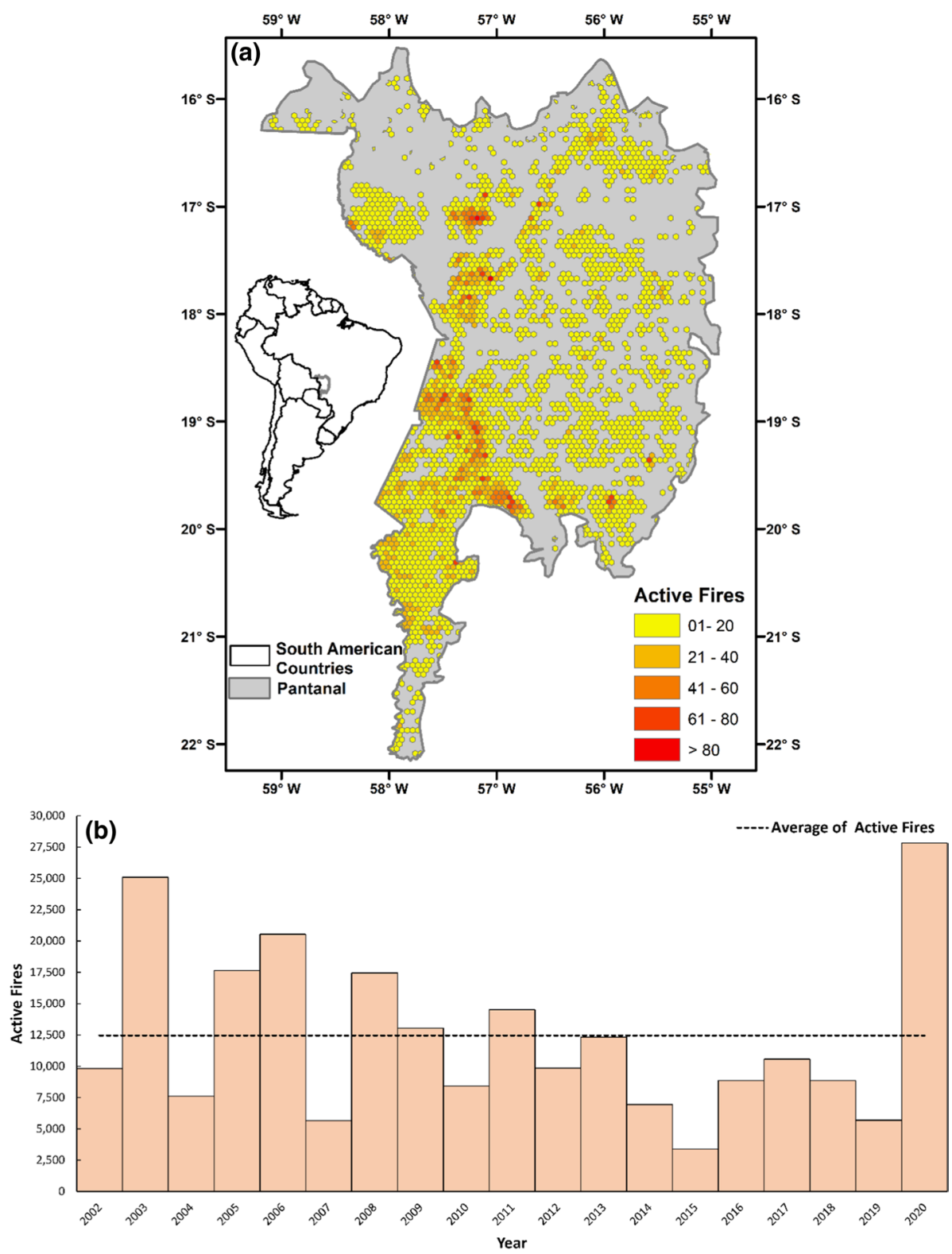

Fig. 2 (a) Location of the Pantanal within South America and location of the active fires detected by MODIS sensors during the hydrological year ended in July, 2020, (b) Annual total of active fires detected by MODIS sensors in the Pantanal from 2002 to 2020 . Active fires were clustered considering a $0.3^{\circ}$ grid 
Approximately $95 \%$ of the 2020 hydrological year active fires occurred in natural land covers (MapBiomas 2020) with, surprisingly, $28 \%$ of them occurring in areas classified as wetlands that likely dried out due to the drought. This highlights the drought crisis in a region depending on the seasonal flooding and river levels for its functioning (Pereira et al. 2021). The traditional peoples of the Pantanal, namely pantaneiros whose majority are cattle ranches, are still suffering severe implications from this historical drought as rainfall variability, river levels, and beef cattle production have a strong connection in the Pantanal (Araujo et al. 2018). The impacts of this crisis on biodiversity, conservation, and Pantanal's traditional people are yet to be understood but we urge the development of a special policy to minimize them.

Public policies should focus on the establishment of Protected Areas (PAs), considered the most effective tool for reducing the loss of natural vegetation (Watson et al. 2018), and government enforcement, a crucial factor for the effectiveness of PAs (Nolte et al. 2013). Currently $4.3 \%$ of the Pantanal is composed of PAs with only $3.5 \%$ of the 2020 hydrological year's active fires occurring within them. However, the increase and effective monitoring of PAs in the Pantanal are not being considered as the current Brazilian Federal policy promotes an anti-environmental agenda (Artaxo 2019). The endangering of wetlands by environmental setbacks is not new, as the Brazilian Forest Code of 2012 (Law $12,651 / 2012$ ) protects areas only to a defined "regular" water level, opening the opportunity of destructing high-lying wetland areas (de Sousa Jr et al. 2011). Other recommendations for the Pantanal recovery and conservation are the dialogue between scientific and traditional ecological knowledge, and to improve public participation and environmental education in and on Pantanal research (Schulz et al. 2019).

These and other concerns, including the preparation and implementation of a biodiversity policy and a social recovery plan for the Pantanal fires, were raised by several scientists across the world in an urgent request to the Brazilian Government (HAW Hamburg 2020) but no response has been received so far.

Author contributions: Conceptualization, G.A.V.M., G.P., G.d.O. and H.T.S.; methodology, G.A.V.M., and H.T.S.; writing — original draft preparation, G.A.V.M., G.d.O. and G.P.; writing—review and editing, F.d.S.C, Y.E.S., F.S.K., N.A.B.

Funding This work was supported by the São Paulo Research Foundation (FAPESP) [Grant Numbers 2019/25701-8, 2016/02018-2] and by the National Council for Scientific and Technological Development (CNPq) [Grant Numbers 381065/2019-7, 441934/2018-8, 441942/2018-0].

\section{Declarations}

Conflict of interest The authors declare that they have no conflicts of interest.

Consent for publication All authors have read and agreed to the published version of the manuscript.

\section{References}

Araujo AGJ et al (2018) Relationships between variability in precipitation, river levels, and beef cattle production in the Brazilian Pantanal. Wetl Ecol Manag 26:829-848. https://doi.org/10.1007/ s11273-018-9612-0

Artaxo P (2019) Working together for Amazonia. Science 363:323. https://doi.org/10.1126/science.aaw6986 
Barlow J, Berenguer E, Carmenta R, Franca F (2020) Clarifying Amazonia's burning crisis. Glob Chang Biol 26:319-321. https://doi.org/10.1111/gcb.14872

de Oliveira G et al (2020) Smoke pollution's impacts in Amazonia. Science 369:634-635. https://doi.org/10. $1126 /$ science.abd5942

de Sousa Jr PT, Fernandez Piedade MT, Candotti E (2011) Ecological oversight: Brazil's forest code puts wetlands at risk. Nature 478:458. https://doi.org/10.1038/478458b

Funk C et al (2015) The climate hazards infrared precipitation with stations-a new environmental record for monitoring extremes. Sci Data 2:150066. https://doi.org/10.1038/sdata.2015.66

HAW Hamburg (2020) Fire in Paradise: Declaration of World Scientists. http://www.haw-hamburg.de/en/ university/newsroom/news-details/news/news/show/fire-in-paradise-declaration-of-world-scientists/. Accessed 23 September 2020

Keddy PA, Fraser LH, Solomeshch AI, Junk WJ, Campbell DR, Arroyo MTK, Alho CJR (2009) Wet and wonderful: The World's largest wetlands are conservation priorities. BioSci 59:39-51. https://doi.org/ 10.1525/bio.2009.59.1.8

Langlois J (2020) Volunteers coming to rescue jaguars, other animals injured during Brazil's wildfires. National Geographic. http://www.nationalgeographic.com/animals/2020/10/volunteers-rescuing-jagua rs-injured-during-brazil-wildfires/\#: :text=A\%20team\%20of\%20volunteer\%20veterinarians, well\%20 connected $\% 20$ before $\% 20$ the $\% 20$ fires. Accessed 05 Ocotber 2020

Lemos V (2020) Queimadas no Pantanal: a luta pela sobrevivência do maior felino das Américas em meio aos incêndios. BBC Brasil. http://www.bbc.com/portuguese/brasil-54153221. Accessed 16 September 2020

Libonati R, DaCamara CC, Peres LF, Sander de Carvalho LA, Garcia LC (2020) Rescue Brazil's burning Pantanal wetlands. Nature 588:217-219. https://doi.org/10.1038/d41586-020-03464-1

MapBiomas (2020) Collection 5 of Brazilian Land Cover \& Use Map Series. http://mapbiomas.org/. Accessed 15 September 2020

Morel L (2020) 'Não pode ser acidente', diz delegado da PF sobre incêndios no Pantanal. Estadão. http:// noticias.uol.com.br/ultimas-noticias/agencia-estado/2020/09/15/nao-pode-ser-acidente-diz-delegadoda-pf-sobre-incendios-no-pantanal.htm. Accessed 16 September 2020

National Institute for Space Research (INPE) (2020) Fire Monitoring Program. http://queimadas.dgi.inpe.br/ queimadas/. Accessed 08 September 2020

Nolte C, Agrawal A, Silvius KM, Soares-Filho BS (2013) Governance regime and location influence avoided deforestation success of protected areas in the Brazilian Amazon. Proc Natl Acad Sci USA 110:4956-4961. https://doi.org/10.1073/pnas.1214786110

Pereira G, Ramos RC, Rocha LC, Brunsell NA, Merino ER, Mataveli GAV, Cardozo FS (2021) Rainfall patterns and geomorphological controls driving inundation frequency in tropical wetlands: How does the Pantanal flood? Prog Phys Geogr. https://doi.org/10.1177/0309133320987719

Pinheiro B (2020) Fumaça das queimadas no Pantanal chega em países vizinhos. Terra. http://www.terra. com.br/noticias/ciencia/sustentabilidade/fumaca-das-queimadas-no-pantanal-chega-em-paises-vizin hos,d473b62ab86c641449952a3265403114ck4g3y9z.html. Accessed 22 September 2020

Schulz C et al (2019) Physical, ecological and human dimensions of environmental change in Brazil's Pantanal wetland: Synthesis and research agenda. Sci Total Environ 687:1011-1027. https://doi.org/10. 1016/j.scitotenv.2019.06.023

Stokstad E (2020) 'The warning lights are flashing.' Report finds nations failing to protect biodiversity. Science. https://doi.org/10.1126/science.abe8098

Thielen D et al (2021) Marine heatwaves in the dynamics of the Pantanal's historical drought and unprecedented fires. EGU General Assembly 2021. https://doi.org/10.5194/egusphere-egu21-9268

Thielen D, Schuchmann KL, Ramoni-Perazzi P, Marquez M, Rojas W, Quintero JI, Marques MI (2020) Quo vadis Pantanal? Expected precipitation extremes and drought dynamics from changing sea surface temperature. PloS one 15:e227437. https://doi.org/10.1371/journal.pone.0227437

Watson JEM et al (2018) The exceptional value of intact forest ecosystems. Nat Ecol Evol 2:599-610. https://doi.org/10.1038/s41559-018-0490-x

Publisher's Note Springer Nature remains neutral with regard to jurisdictional claims in published maps and institutional affiliations. 